\title{
MAPK Activity in Porcine Oocytes Maturing InVitro
}

\author{
Jae-Dal Lee 1* $^{*}$ \\ ${ }^{1}$ Department of Pet Care, Hyejeon College \\ 유사분열 활성화 단백질 효소가 돼지난자의 \\ 체외성숙에 미치는 영향 \\ 이재달 ${ }^{*}$ \\ ${ }^{1}$ 혜전대학 애완동물관리과
}

\begin{abstract}
In this study, we determined effects of the mitogen-activated protein kinase (MAPK) inhibitor, U0126 on meiotic maturation, microtubule organization and actin filament assembly in the porcine oocyte. The phosphorylated MAPK was first detected at $12 \mathrm{~h}$ after the initiation of maturation cultures, fully activated at $24 \mathrm{~h}$, and remained until metaphase II. Treatment of germinal vesicle (GV) stage oocytes with $20 \mu \mathrm{M}$ U0126 completely blocked MAPK phosphorylation, but germinal vesicle breakdown (GVBD) was normally proceeded. However, the oocytes didn't progress to the metaphase I. The inhibition of MAPK resulted in abnormal spindles. In oocytes treated with U0126 after GVBD, polar body extrusion was normal, but the organization of the metaphase plate and chromosome segregation were abnormal. In conclusion, MAPK activity plays an important regulatory role in GV chromatin configuration and meiotic progress in porcine oocyte maturation.

요 약 본 연구에서는 MAPK 저해제인 U0126이 난자성숙과정에서 특히 감수분열, 미세소관 형성 그리고 액틴 필 라먼트 형성에 미치는 영향을 조사하였다. 그 결과 MAPK 단백질은 12시간째에 인산화되기 시작하여, 24시간째에 대부분 인산화 되었고 metaphase II에 이르기 까지 유지되었다. 배포단계 $(\mathrm{GV})$ 에 있는 난자를 U0126의 $20 \mu \mathrm{M}$ 농도로 처리하였을 때 MAPK의 인산화가 완전히 억제되었으나 배포의 파열 단계(GVBD)로의 성숙에는 진행하였으나, metaphase I까지는 발달하지 못하였다. 또한 MAPK 저해제로 인해 비정상적인 방추사의 형성을 초래하였다. 난자를 배포의 파열단계(GVBD) 이후에 U0126을 처리하였을 때 극체의 방출은 정상 이였으나 중기 판의 배열과 염색체의 분열은 비정상적 이였다. 결론적으로, 유사분열 활성화 효소단백질인 MAPK의 활성은 돼지 난자의 체외성숙과정에서 배포단계 $(\mathrm{GV})$ 의 염색체의 배열과 감수분열의 완성에 중요한 조절 인자임을 이번 연구를 통해 알 수 있었다.
\end{abstract}

Key Words : oocyte maturation, MAPK, microtubules, actin filaments

\section{INTRODUCTION}

In most mammals, fully grown follicular GV oocytes are arrested at G2 phase, the so-called germinal vesicle (GV) stage of development. The oocytes resume meiosis in response to specific signals, often hormone, or after being liberated from their follicular environment. Following germinal vesicle breakdown (GVBD), chromatin is condensed, the metaphase I (MI) spindle is organized [1]. The oocytes develop to metaphase of second meiosis (MII), where it extrudes first polar body and maintains a second meiotic arrest until fertilization. The family of MAPK (p42 and p44), also known as extracellular signal-regular kinase (ERK1 and ERK2), is serine/ threonine kinase that requires threonine and tyrosine phosphorylation to become fully active. Both ERK1 and ERK2 are phosphorylated and activated by MAPK kinase (MEK). The MAPK is activated during the

*Corresponding Author : Jae-Dal Lee(jdlee@hj.ac.kr)

Received March 25, $2010 \quad$ Revised April 13, $2010 \quad$ Accepted June 18, 2010 
whole oocyte maturation process and reachs maximal level at MII. It is proposed that MAPK plays a pivotal role in meiosis. MAPK activity is associated with the microtubule organization and cell cycle progression during pig oocyte [2]. Uring is a potent and specific inhibitor of MEK1 and MEK2, the kinases that phosphorylate and, thus, activates ERK type MAPKs [3]. In porcine oocytes, inhibition of ERK activity using Uring during the meiosis I /meiosis II transition suppressed chromosome separng Urinfirst polar body emission and formation of the MII spindle $[3,4]$.

In contrast, a significant fraction of porcine oocytes treated with U0126 at MII completed the second meiotic division and entered interphase [5]. Although MAPK activity is implicated in controlling meiotic spindle formation, little information is available on the effect of MAPK on cytoskeletal components in mammalian oocytes maturing in vitro. Therefore, the present study examined the effect of the MAPK pathway inhibitor U0126 on microtubule organization, and microfila -ments assembly in pig oocytes maturing in vitro.

\section{MATERIALS AND METHODS}

\subsection{Porcine oocyte collection, In vitro maturation, and U0126 treatments}

Porcine ovaries were obtained from gilts at commercial slaughterhouse and transported to the laboratory at $25^{\circ} \mathrm{C}$ in salin. For the collection of porcine cumulus-oocyte complex (COCs) were aspirated from follicles $(2-5 \mathrm{~mm}$ in diameter) with an18-gauge needle and a syringe. COCs with intact unexpended cumulus cells were isolated from cellular debris and rinsed three times in HEPES. These experiments use a basic culture medium consisting of TCM199 medium supplemented with $0.4 \%(\mathrm{w} / \mathrm{v})$ BSA, 10 IU EGF, $10 \mathrm{IU}$ hCG, and $10 \mathrm{IU}$ PMSG. The effects of U0126 (Cell Signaling Technology, Beverly, MA) on IVM of pig oocytes were examined as follows. U0126 was added to the culture medium at concentrations of $10-30 \mu \mathrm{M}$ since these concentrations exerted a significant stimulatory effect on the maturation of pig oocytes in our previous study. COCs were cultured in a $500 \mu 1$ droplet of TCM 199 in the presence or absence of $20 \mu \mathrm{M}$ U0126 under mineral oil at $39^{\circ} \mathrm{C}$ in a humidified atmosphere containing $5 \% \mathrm{CO}_{2}$ for $44 \mathrm{~h}$.

\subsection{Western blot analysis}

Oocytes (15 oocytes per sample) were solubilized in 20 $\mu 1$ 1X SDS Sample Buffer (62.5 mM Tris-HCl), 2\% w/v SDS, $10 \%$ glycerol, $50 \mathrm{mM}$ DTT, $0.01 \% \mathrm{w} / \mathrm{v}$ bromophenol blue or phenol red) and heated for $5 \mathrm{~min}$ at $95^{\circ} \mathrm{C}$. For Western analysis, proteins were resolved on a $5-12 \%$ Tris-SDS page ge 1 for $1 \mathrm{~h} 30 \mathrm{~min}$ at $80-100 \mathrm{~V}$. Samples were transferred to a nitrocellulose membrane (Amersham, Hybond-ECL) at $300 \mathrm{~mA}$ for $2 \mathrm{~h}$ using transfer buffer. After blocking with $5 \%$ skim milk in PBS for $1 \mathrm{~h}$, the membrane was incubated for at least $2 \mathrm{~h}$ with a phospho p44/42MAPK antibody (Cell Signaling Technology, Beverly, MA) diluted 1:300 in blocking solution (1XTBS, $0.1 \%$ Tween-20, $5 \% \mathrm{w} / \mathrm{v}$ nonfat dry milk), washed three times in TBST (20mM Tris.HCl (pH7.5), 250mM NaCl,0.1 $\%$ Tween 20), and incubated for $1 \mathrm{~h}$ with an HRP-linked anti-rabbit IgG (Cell Signaling Technology, Beverly,MA) diluted 1:2000 in blocking solution. After three washes with TBST, antibody binding was visualized using a Chemiluminescence Luminol Reagent (Invitrogen).

\subsection{Immunofluorescence and confocal microscopy}

Approximately 30 oocytes in three replicates were collected at various time points during in vitro maturation. The oocytes were fixed with $4 \%$ paraformaldehyde, and stained for microtubules, $\gamma$-tubulin, actin, and NuMA. The following anti-bodies were used: monoclonal anti- $\alpha$ -tubulin clone B-512 (Sigma, St. Louis, MO), phalloidin-FITC (Sigma), anti-NuMA (BD Biosciences, NJ, USA). The samples were incubated with the secondary antibody, an anti-mouse IgG-FITC. The nuclear status of the oocytes was evaluated by staining with propidium iodide. The phase-contrast images of individual samples were digitized using laser scanning confocal microscopy (Leica Laser Technik $\mathrm{GmbH}$ ) and MetaMorph software.

\section{RESULT}




\subsection{Effect of U0126 on MAPK phosphorylation of porcine oocyte maturation}

In order to determine the concentration of U0126 which would effectively inhibit activation of MAPK, oocytes were cultured for $24 \mathrm{~h}$ in medium containing 0 , 10 or $20,30 \mu \mathrm{M}$ U0126. The amount of activated MAPK was significantly reduced in a dose dependent manner [Fig 1A]. MAPK activity was completely absent when oocytes were cultured in the presence of $20 \mu \mathrm{M}$ U0126 for 14h (Fig 1B). However, when U0126 was added to cultures at $4 \mathrm{~h}$ after initiation of in vitro oocyte maturation, the MAPK activity was not completely, but significantly inhibited after $14 \mathrm{~h}$ in the maturation culture.

When GV oocytes were cultured in medium containing $20 \mu \mathrm{M}$ U0126 for $9 \mathrm{~h}$, the oocytes underwent GVBD, but were significantly inhibited in progression to the MI stage as compared to controls (Control; $76.7 \pm 5.66 \%, 10 \mu \mathrm{M}$ U0126; 29.0 $\pm 7.35 \%, 20 \mu \mathrm{M}$ U0126; 26.4 $\pm 5.74 \%$ ). Polar body extrusion was observed in most oocytes when cultured in the presence of $20 \mu \mathrm{M} \mathrm{U} 0126$ at $4 \mathrm{~h}$ after initiation of in vitro oocyte maturation to $14 \mathrm{~h}$ into the in vitro maturation incubation (Control ;76.6 $\pm 4.21 \%, 20 \mu \mathrm{M}$ U0126; 70.7 $\pm 4.61 \%$ ). However, there was an decrease in normal MII stage oocytes when cultured for 4 to $14 \mathrm{~h}$ (Control; 87.7 $\pm 5.12 \%, 20 \mu \mathrm{M}$ U0126; 32.8 $\pm 3.79 \%$ ), for example of abnormality, polar body lacking a nucleus, as well as abnormal spindle or metaphase plate.

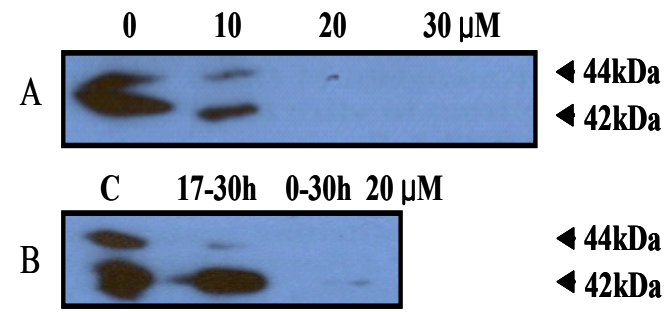

[Fig. 1] Western blot analysis of MAPK in the porcine oocytes during oocyte maturation. A, porcine oocytes were cultured in medium for $44 \mathrm{~h}$ in the presence of $0,10,20$, or $30 \mu \mathrm{M}$ U0126. B, porcine oocytes were cultured in the presence of $20 \mu \mathrm{M}$ U0126 for $0,17-30$, or $0-30 \mathrm{~h}$ of the in vitro maturation.

\subsection{Effect of U0126 on microtubule and actin filaments}

At GV stage oocytes, the microtubules were found in the cortex and some in near the vesicle [Fig. 2Aa]. Following GVBD, numerous small microtubule asters were produced near the chromatin [Fig. 2Ab] and formed a spindle at MI stage oocytes. The oocytes in which GVBD was arrested by U0126 treatment had several types of abnormal microtubule assembly [Fig. 2Ac]. In some cases, a disorganized array of microtubules formed around the chromatin [Fig. 2Ad], some oocytes had microtubules in a side near the chromatin [Fig. 2Ae], and others had incomplete spindles [Fig. 2Af]. Actin filaments were observed in the cytoplasm cortex at the GV stage oocytes [Fig. 2Ba]. Following GVBD numerous actin filaments emanate from the plasma membrane and form a cortical actin-rich layer following GVBD [Fig. 2Bb]. The actin filament network was not altered in U0126 treated oocytes arrested at GVBD [Fig. 2Bc\&d]. Furthermore, normal actin filament assembly was observed during polar body emission in oocytes treated with U0126 from 4- to $14 \mathrm{~h}$ after initiation of in vitro maturation[Fig. $2 \mathrm{Be} \& \mathrm{f}$ ].

\section{DISCUSSION}

In mammalian cells, MAPK is activated by MEK phosphorylation upon stimulation of the cells by various growth factors [6,7]. Activated MAPK that remains in the cytoplasm can regulate mitotic microtubule dynamics by influencing the phosphorylation state of microtubule associated proteins [8]. Our results, which are consistent with previous observations [9]. showed that MAPK activation occurred after GVBD, indicating that MAPK is not required for GVBD but is involved in regulating post-GVBD events .

Inhibition of MAPK activity by treatment with U0126 and arrest at the GVBD stage supports the hypothesis that MAPK activity is involved in formation of the metaphase plate. Previous studies have shown that MAPK activity is responsible for the control of microtubule and chromatin organization in mouse and porcine oocytes [4,10]. An upstream activator of MAPK, MOS, has also been shown to control microtubule and chromatin organization. 


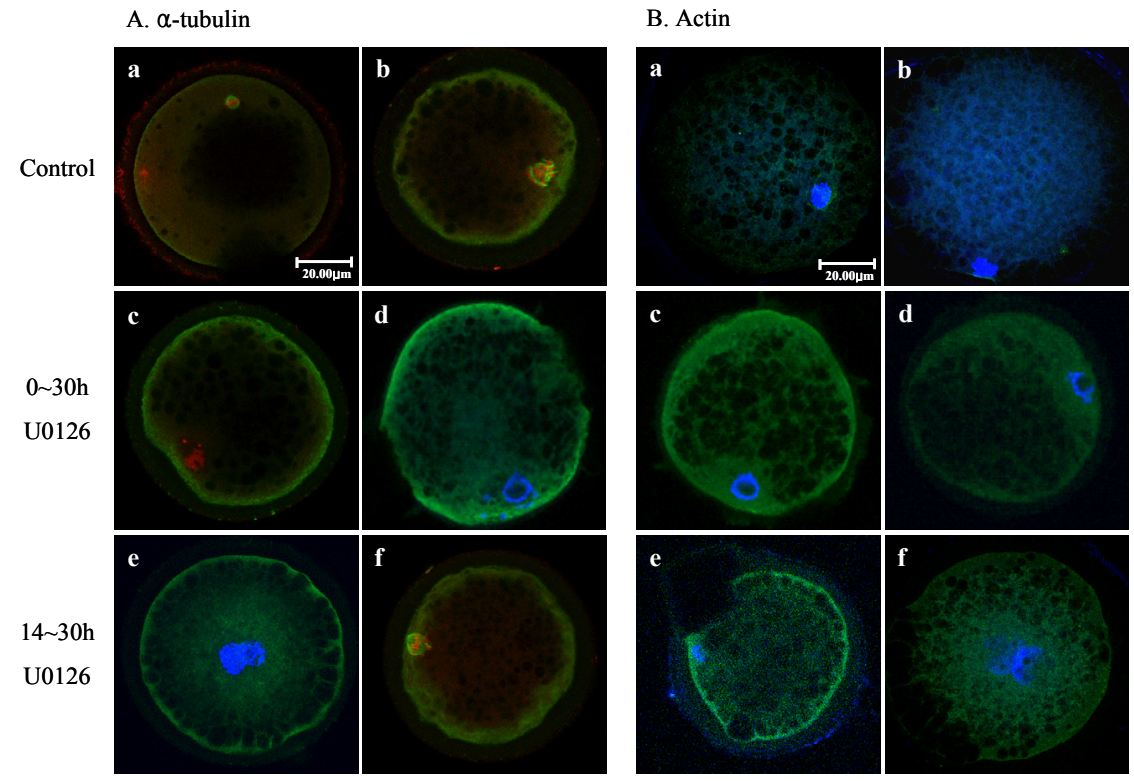

[Fig. 2] Immunofluorescent localization of microtubules and actin filament in porcine oocytes during in vitro maturation in the presence or absence of $20 \mu \mathrm{M}$ U0126. A, microtubule ;B, actinfilament. Green, microtubules (A) or actin filament (B); red or blue, chromatin.

MAPK was not activated in c-mos knockout mouse oocytes and abnormal spindles, loosely condensed chromosomes, and large polar bodies were observed $[11,12]$. Similarly, in the present study, abnormal assembly of microtubules was detected in U0126 treated, GVBD arrested oocytes.

Actin filaments that are associated with the plasma membrane are important for generating cell-surface specialization areas and also provide the driving force for cell surface remodeling. The mouse oocyte cortexl susesses numerous actin filaments that emanate from the plasma membrane, forming a uniform layeraof F-actin. This layeraof actin filaments appears to anchor the spindle and force polar body extrusion. In the present study, we did not detect any disassembly of actin filaments in U0126 treated, GVBD arrested oocytes. Furthermore, polar body extrusion rates were on areducnd allowing U0126 treatment. This suggests that MAPK is not involved in actin filament assembly or its function in polar body extrusion.

In conclusion, the meiotic abnormalities caused by U0126, a specific inhibitor of MEK, indicate that the MEK/MAPK pathway is an important regulator of microtubule and centrosome assembly, but not actin filament assembly.

\section{참고문헌}

[1] Sun QY, Schatten H. Regulation of dynamic events by microfilaments during oocyte maturation and fertilization. Repro -duction 131193-205. 2006.

[2] Sun QY, Lai L, Park KW, Kuhholzer B, Prather RS, Schatten H. Dynamic events are differently mediated by microfilaments, microtubules, and mitogen-activated protein kinase during porcine oocyte maturation and fertilization invitro. Biol Reprod 64871- 889. 2001

[3] Favata MF, Horiuchi KY, Manos E J. Identification of a novel inhibitor of mitogen-activated protein kinase kinase. J Biol Chem 273 18623-32. 1998.

[4] Lee J, Miyano T, Moor RM. Localization of phosphorylated MAP kinase during the transition from meiosis I to meiosis II in pig oocytes. Zygote 8119-25. 2000.

[5] Tatemoto $\mathrm{H}$, Muto N. Mitogen-activated protein kinase regulates normal transition from metaphase to interphase following parthenogenetic activation in porcine oocytes. Zygote 9 15-23. 2001.

[6] Pelech SL, Sanghera JS. MAP kinases: charting the regulatory pathways. Science 257 1355-6. 1992.

[7] Davis R. The mitogen-activated protein kinase signal transduction pathway. J Biol Chem 268 14553-14556. 1993. 
[8] Morishima-Kawashima M, Kosik KS. The pool of MAP kinase associated with microtubules in small but constitutively active. Mol Biol Cell 7893-905. 1996.

[9] Inoue $M$, Naito $K$, Nakayama $T$, Sato $E$. Mitogen-activated protein kinase translo -cates into the germinal vesicle and induces germinal vesicle breakdown in porcine oocytes. Biol Reprod 58 130-136. 1998.

[10] Verlhac MH, Pennart HD, Maro B, Cobb MH, Clarke HJ. MAP kinase becomes stably activated at metaphase and in associated with microtubuleorganizing centers during meiotic maturation of mouse oocytes. Dev Biol 158 330-340. 1993.

[11] Araki K, Naito K, Haraguchi S, Suzuki R, Yokoyama M, Inoue M, Aizawa S, Toyoda Y, Sato E. Meiotic abnormalities of c-mos knockout mouse oocytes: activation after first meiosis or entrance into third meiotic metaphase. Biol Reprod 551 315-24. 1996.

[12] Choi T, Fukasawa K, Zhou R, Tessarollo L, Borror K, Resau J, Vande Woude GF. The Mos/mitogen -activated protein kinase (MAPK) pathway regulates the size and degradation of the first polar body in maturing mouse oocytes. Proc Natl Acad Sci USA 93 7032-7035. 1996.

Jae-Dal Lee

[Regular member]

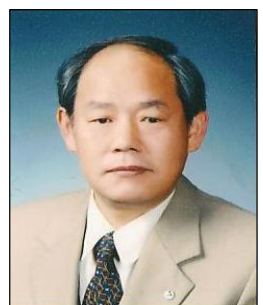

- Feb. 1977 : ChungNam National Univ., Dept. of Textile Engineering

- Feb. 1990 : ChungNam National Univ., Dept. of Textile Engineering, MS

- Feb. 1999 : ChungNam National Univ., Dept. of Textile Engineering, $\mathrm{PhD}$

- Aug. 2007 : ChungBuk National Univ., Dept. of Animal Science Graduate, MS

- Mar. 1995 current : Hyejeon College, Dept. of Pet Care, Professor

$<$ Research Interests $>$

Animal Reproductive Physiology 